\title{
BAHAN AJAR STATISTIKA BERBASIS GENERATIVE LEARNING UNTUK MENINGKATKAN KEMAMPUAN PEMAHAMAN MATEMATIS
}

\author{
Yenni Yenni ${ }^{1}$, Retno Andriyani ${ }^{2}$ \\ ${ }^{1}$ Universitas Muhammadiyah Tangerang \\ yenni_aan@yahoo.co.id \\ ${ }^{2}$ Universitas Muhammadiyah Tangerang \\ retno_andriani90@yahoo.co.id
}

\begin{abstract}
ABSTRAK
Penelitian ini bertujuan untuk: 1) menghasilkan bahan ajar dan latihan statistika berbasis metode generative learning, 2) mengetahui efek bahan ajar terhadap kemampuan pemahaman matematis mahasiswa pada mata kuliah statistika. Penelitian menggunaka metode design research. Subjek penelitian ini yaitu mahasiswa program studi pendidikan matematika kelas pagi yang berjumlah 49 mahasiswa. Tahapan penelitian pengembangan mengacu pada lima langkah tahapan, yaitu analysis, design, development, implementation, dan evaluation. Teknik penumpulan data dengan angket validitas ahli materi, ahli media, ahli pendidikan, instrument wawancara, evaluasi mahasiswa serta tes. Berdasarkan hasil penelitian, Bahan ajar dan latihan statistika berbasis generative learning berada pada level baik. Hasil angket evaluasi mahasiswa mengenai efek bahan ajar berada pada tingkat baik. Hasil tes kemampuan pemahaman matematis pada mata kuliah statistika berada pada level sangat baik. Hal ini terlihat dari nilai kepraktisan, yaitu bahwa nilai akhir mahasiswa pada mata kuliah statistika ini berada pada nilai baik dan sangat baik.
\end{abstract}

Kata Kunci: bahan ajar, statistika, pemahaman matematis, generative learning

\begin{abstract}
This study aims to produce teaching materials and statistical exercises based on generative learning methods; find out the effects of teaching materials on students' mathematical understanding skills in statistical subjects. The subjects of this study were 49 students of the mathematics education program. The study uses design research with stages of development research, namely analysis, design, development, implementation, and evaluation. Data collection techniques with questionnaire validity of material experts, media experts, education experts, interview instruments, student evaluations, and tests. Based on the results of the study, teaching materials and statistical exercises based on generative learning are at a good level. The results of the student evaluation questionnaire regarding the effect of teaching materials are at a good level. The results of the mathematical comprehension ability test on statistical subjects are at a very good level. This can be seen from the value of practicality, namely that the final grade of students in the statistics course is in good and very good grades.
\end{abstract}

Keywords: teaching materials, statistics, mathematical understanding, generative learning 
Format Sitasi: Yenni, Y. \& Andriani, R. (2019). Bahan Ajar Statistika Berbasis Generative Learning untuk Meningkatkan Kemampuan Pemahaman Matematis. Kalamatika: Jurnal Pendidikan Matematika, 4(2), 151-162.

Penyerahan Naskah: 17 Juli 2019 || Revisi: 25 November 2019 || Diterima: 28 November 2019

\section{PENDAHULUAN}

Kemampuan pemahaman matematis mutlak diperlukan dalam mempelajari materi statistika. Kemampuan ini sangat berperan dalam mencapai hasil maksimal. Pemahaman konsep yang tidak cukup akan memperlambat proses pengetahuan karena penguatan konsep yang kurang. Hal ini sependapat dengan Ompusunggu (Ompusunggu, 2014) yang mengungkapkan tanpa adanya pemahaman konsep dasar yang kuat, maka peserta didik akan tidak mampu memahami konsep yang diberikan. Permasalahan dengan tema pemahaman konsep juga ditemukan oleh Fitri (2017). Pada kasus SMAN 10 dan SMA 12 Pekanbaru peserta didik tidak mendapatkan kesempatan untuk mengembangkan kemampuannya, hal tersebut dikarenakan proses pembelajaran kurang melibatkan keaktivan peserta didik.

Pemahaman matematis yang mendalam pada suatu konsep akan dapat mengembangkan pengetahuan pada matematika. Artinya, semakin dalam pemahamanan, semakin seseorang dapat mengembangkan suatu konsep dan ide yang dimiliki guna meyelesaikan permasalahan matematika. Lingkup pemahaman matematis seperti kemampuan penerapan konsep, kemampuan mengungkapkan dengan Bahasa sendiri, kemampuan perhitungan serta menerapkannya dalam penyelesaian masalah sangat besar peranannya dalam meyelsaikan masalah matematika yang lainnya. Hal serupa diungkapkan oleh Purwosusilo (2014), bahwa kemampuan pemahaman matematis adalah kemampuan memahami konsep, memahami rumus dan mampu menggunakan konsep dan rumus tersebut dalam perhitungan, serta pemahaman tentang skema atau struktur yang dapat digunakan pada penyelesaian masalalah yang lebih luas dan sifat pemakaiannya yang lebih bermakna. Hal serupa diungkapkan oleh Indriani, dkk (2019) bahwa pemahaman matematis merupakan landasan penting untuk berpikir dalam meyelesaikan persoalan-persoalan matematika maupun persoalan-persoalan di kehidupan sehari-hari.

Mengingat pentingnya peranan kemampuan pemahaman konsep ini, maka menjadi kewajiban semua pengajar untuk dapat memfasilitasi agar kemampuan ini dapat berkembang. 
Salah satunya dengan memberikan sarana yang tepat. Sarana pembelajaran yang sering digunakan dalam pembelajaran adalah modul. Modul dapat digunakan sebagai kunci pembelajaran, jika didesain dengan tepat. Kasus pemahaman matematis pada mahasiswa PGPAUD Universitas Muhammadiyah Tangerang juga menjelaskan, bahwa alat bantu dan sarana pembelajaran sangat berpengaruh dalam meningkatkan kemampuan pemahaman matematis mahasiswa (Yenni, 2017). Dengan menggunakan alat bantu yang tepat, suatu kemampuan dapat dimaksimalkan. Termasuk didalamnya adalah kemampuan pemahaman matematis. Sejalan dengan Nurafni, dkk (2019) yang menyatakan bahwa bahan ajar merupakan faktor penting dalam kegiatan pembelajaran di kelas. Bahan ajar yang disusun dan dirancang secara sistematis memungkinkan mahasiswa dapat belajar secara mandiri. Pendapat lain yang mendukung, yaitu oleh Mahyudi, Ariani, Ramadianti (2017); Monalisa, Trapsilasiwi (2017), yang meyatakan bahwa pemilihan dan penggunaan bahan ajar yang tepat dalam suatu aktivitas dan proses pembelajaran berperan penting dalam mengarahkan pengalaman belajar.

Kemampuan pemahaman matematis mahasiswa pendidikan matematika di awal pembelajaran masih menunjukkan tingkat pemahamanan yang rendah. Pada tes awal, berupa pemberian soal staistika sederhana yang diberikan kepada mahasiswa, banyak mahasiswa menjawab dengan cara serupa. Temuan penggunaan rumus dan penyajian data yang hampir sama sejumlah 64\%. Hal ini menunjukkan bahwa pemahaman representasi mahasiswa masih kurang. Oleh karena itu, penelitian ini bermaksud untuk menghasilkan bahan ajar yang dapat meningkatkan kemampuan pemahaman matematis mahasiswa.

\section{Metode Generative Learning}

Salah satu model pembelajaran yang diprediksi dapat mempengaruhi kemampuan pemahaman matematis mahasiswa pada mata kuliah statistika adalah Generative Learning. Metode ini efektif karena didalamnya terdapat langkah-langkah: 1) eksplorasi; 2) pemfokusan; 3) tantangan; dan penerapan. Mahasiswa akan dituntut untuk mencari pengetahuan baru, selanjutnya ditantang mengaplikasikan pengetahuan barunya kedalam permasalahan yang telah dibaca dan didiskusikan sebelumnya. Dengan demikian, dosen bertindak sebagai fasilitator saja. Model yang dilengkapi dengan tahapan diharapkan dapat menuntun mahasiswa untuk belajar secara terurut. Pendapat ini diperkuat oleh Hakim (2014). Yaitu bahwa peran utama guru dalam model pembelajaran generatif yaitu guru sebagai stimulator rasa ingin tahu, guru membangkitkan dan menantang ideide peserta didik, guru sebagai narasumber, dan guru 
sebagai senior co-investigerator. Hal serupa diungkap oleh Sudyana, dkk (2017); Sharfina, Halim, Safitri (2017), bahwa model generatif akan menuntun peserta didik dalam mengkonstruksi makna dari informasi yang ada.

Kelebihan dari generative learning yaitu salah satunya membuat siswa menjadi lebih aktif dalam kegiatan pembelajaran, khususnya dalam mengungkapkan pikiran atau pendapat atau pemahamannya terhadap konsep. Agar siswa menjadi lebih aktif maka siswa perlu mengembangkan keterampilan berdiskusinya (Karlina, Bektiarso, Lesmono: 2014). Keefektifan dan respon positif dari penggunaan model generative learning antara lain dibuktikan dalam penelitian Sugilar (2013), Pratama, Kusumo, Susatyo (2014) dan Wisnuwijanarko (2018).

\section{METODE PENELITIAN}

Metode penelitian yang digunakan dalam penelitian ini adalah jenis penelitian pengembangan. Untuk mengembangkan bahan ajar, tahapan yang digunakan adalah analysis, design, development, implementation, dan evaluation (ADDIE).

Mengacu desain ADDIE pada Hasyim (2016), maka kegiatan penelitian ini dirinci sebagai berikut:

1. Analisis. Studi lapangan dan literatur. Kagiatan yang di analisis pada tahap ini adalah analisis kebutuhan untuk menentukan kemampuan dan kompetensi yang diperlukan untuk meningkatkan kemampuan mahasiswa. Peneliti melakukan kajian awal tentang bagaimana kemampuan awal mahasiswa pada pemahaman matematisnya. Permasalahn tersebut selanjutnya dihubungkan dengan factor-faktor yang menyebabkan masalah tersebut terjadi.

2. Desain. Menentukan kompetensi khusus, metode, bahan ajar dan strategi pembelajaran. Pada langkah ini beberapa hal yang dilakukan peneliti adalah menentukan jenis pengalaman belajar yang akan diterapkan. Sebagai bahan pertimbangan, peneliti mengurutkan keperluan sebagai berikut: a. kemampuan apa yang harus mahasiswa miliki pada statistika pada ranah pemahaman matematis? ; b. bagaimana merumuskan indikator kerja, sehingga kebutuhan pada point a dapat terlaksana?; c. bagaimana strategi pemberian latihan agar yang hendak ditingkatkan dapat berhasil maksimal?

3. Pengembangan. Memproduksi bahan ajar dan alat latihan yang dipergunakan. Yang dilakukan antara lain: a. merancang desain produk; b. menyusun, mengembangkan metode, dan strategi; c. mengembangkan bahan ajar yang telah ada; d. mengembangkan alat 
evaluasi; e. memilih dan mengkombinasikan media yang terbaik untuk dapat dipergunakan dalam pembelajaran.

4. Implementasi, Menerapkan desain. Yaitu penyampaian materi dan penggunaan bahan ajar dari peneliti ke mahasiswa. Pada proses ini, perlu dipastikan bahwa terdapat pembimbingan kepada mahasiswa dengan tujuan mencapai kompetensi yang telah ditetapkan

5. Evaluasi. Pada langkah ini evaluasi dimaksudkan sebagai hasil dari proses yang telah dilakukan. Yang termasuk dalam evaluasi adalah data evaluasi mahasiswa dan nilai akhir mahasiswa setelah mengikuti perkuliahan statistika. Evaluasi mahasiswa berkaitan dengan pendapat mahasiswa pada bahan ajar yang digunakan meliputi bagaimana tampilan bahan ajar, pengetahuan baru pada statistika yang diperoleh, serta manfaat yang dirasakan setelah belajar dengan bahan ajar.

Subjek dari penelitian ini adalah mahasiswa program studi pendidikan matematika, fakultas keguruan dan ilmu pendidikan, Universitas Muhammadiyah Tangerang. Penelitian dilaksanakan pada semester ganjil Tahun Akademik 2018/2019.

Alat instrumen yang digunakan yaitu:

1. Lembar validasi untuk ahli pendidikan.

2. Lembar validasi untuk ahli media.

3. Lembar validasi untuk ahli materi.

4. Lembar wawancara mahasiswa.

5. Lembar evaluasi mahasiswa.

6. Instrumen soal pemahaman matematis.

\section{HASIL DAN PEMBAHASAN}

Tujuan dari penelitian ini adalah menghasilkan bahan ajar yang dapat dipergunakan untuk meningkatkan kemampuan pemahaman matematis mahasiswa dalam mata kuliah statistika yang valid, praktis dan efektif bagi mahasiswa program studi pendidikan matematika Universitas Muhammadyah Tangerang. Untuk menmperoleh hasil tersebut, penelitian ini dilakukan melalui prosedur ADDIE.

Berdasarkan langkah-langkah pada ADDIE tersebut diperoleh hasil sebagai berikut:

1. Tahap Analisis. Tahap ini adalah analisis kebutuhan dan literatur. Kebutuhan bahwa hendak mencapai kemampuan pemahaman matematis yang maksimal. Di awal, peneliti mendapatkan data, bahwa dijumpai $64 \%$ mahasiswa menjawab soal dengan cara yang 
sama. Pemahaman yang ada pada mahasiwa ada, namun belum mengerucut ke indikator yang dimaksudkan. Pada studi literature, peneliti mendapatkan data bahwa mahasiswa telah mengenal statistika dari sekolah menengah pertama dan sekolah menengah atas. Pengetahuan tersebut cukup. Namun, belum berkembang. Terbukti dari tes awal, mahasiswa cenderung menjawab dengan cara sama. Berdasarkan hasil wawancara dengan mahasiswa, hal tersebut dilakukan cenderung meniru cara guru di sekolah menengah (61\%), kebiasaan (55\%), dan alasan mengisi dengan cara termudah yang diketahui oleh mahasiswa (48\%).

Setelah mengetahui bahwa indikator pada kemampuan pemahaman matematis belum maksimal beserta faktor penyebabnya, study literature dilanjutkan pada materi ajar. Materi ajar berkaitan dengan dengan modul sebelumnya yang belum dikelompokkan dan mengerucut pada indikator pamahaman matematis. Pada modul statistika yang lama telah tersedia materi dan latihan. Bahasan mengenai materi ajar akan dibahas lebih lengkap pada tahap desain.

Selanjutnya, study literature dilanjutkan pada alasan cara guru mengajar. Hal ini masuk ke ranah metode pembelajaran. Metode termasuk pada bahasan yang mempengaruhi pengetahuan awal mahasiswa. Bahasan metode pembelajaran lebih lengkap pada tahap desain.

2. Tahap desain. Pada tahap ini beberapa hal yang dilakukan oleh peneliti antara lain:

a. Menetapkan indicator dari pemahaman matematis yang diteliti. Indikator tersebut yaitu, menyatakan ulang sebuah konsep; menyebutkan contoh dan non contoh; menggunakan konsep untuk meyelesaikan masalah, dan menyajikan konsep dalam berbagai bentuk representasi matematik.

b. Menetapkan Jenis bahan ajar. Jenis yang pilih adalah modul dengan ukuran A4. Modul dipilih karena didalamnya memuat materi, contoh kasus dan latihan soal. Dengan kelengkapan tersebut, indikator pemahaman yang hendak dimaksimalkan disusun sedemikian rupa dengan kegiatan dan latihan soal sehingga mahasiswa akan terbiasa dengan pengetahuan baru tersebut. Harapan yang diinginkan adalah mahasiswa dapat membangun pengetahuan dengan merasa nyaman melalui pembiasaan yang diberikan. 


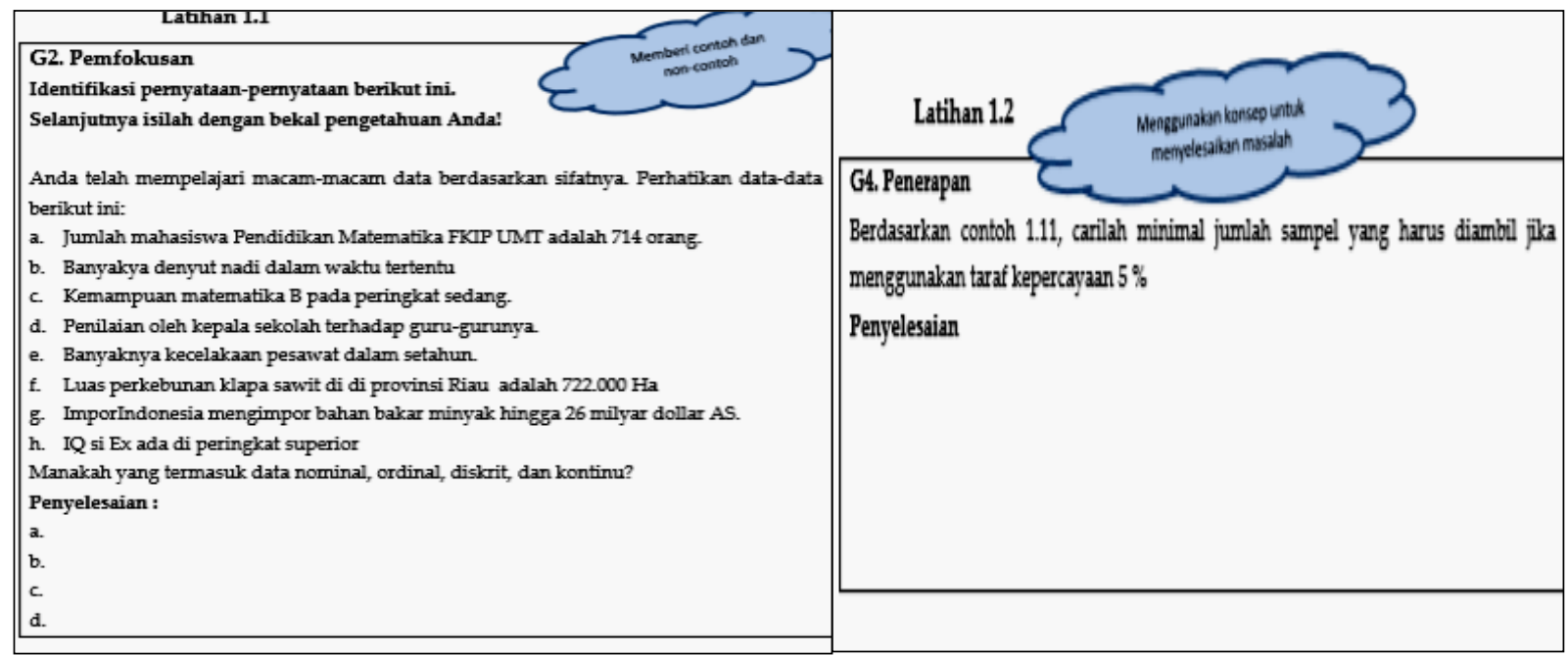

Gambar 1. Setiap Soal Memuat Indikator Pemahaman

c. Memilih metode yang tepat. Metode tepat sangat penting. Pemilihan metode didasarkan agar kegiatan setiap langkah dapat memberikan pembiasaan, makna dan mengkontruksi pengetahuan baru. Dengan demikian, pengalaman dalam pembelajaran akan berbekas pada ingatan dan ketrampilan menjawab. Metode yang dipilih adalah Generative learning dengan urutan langkah-langkah; 1) eksplorasi; 2) Pemfokusan; 3). Tantangan; dan 4) Penerapan. Pada tahap eksplorasi, mahasiswa mendapat pengetahuan baru dengan membaca dan penjelasan dari dosen. Selanjutnya, pengetahuan baru dilatih dengan mengamati suatu kasus, beserta penyelesaian masalahnya. Setelah memahami contoh kasus dan masalah, mahasiswa ditantang untuk meyelesaikan permasahan yang serupa secara individu atau berkelompok. Dengan demikian, mahasiswa diharapkan lebih memahami dan terampil dalam mengerjakan kasus pada statistika sesuai dengan apa yang telah dipelajari. Tahap terakhir adalah penerapan. Berdasarkan pengetahuan yang telah didapat, mahasiswa diharapkan dapat menyelesaikan secara individu permalahan statistika yang berkaitan dengan indikator pemahaman matematis. 


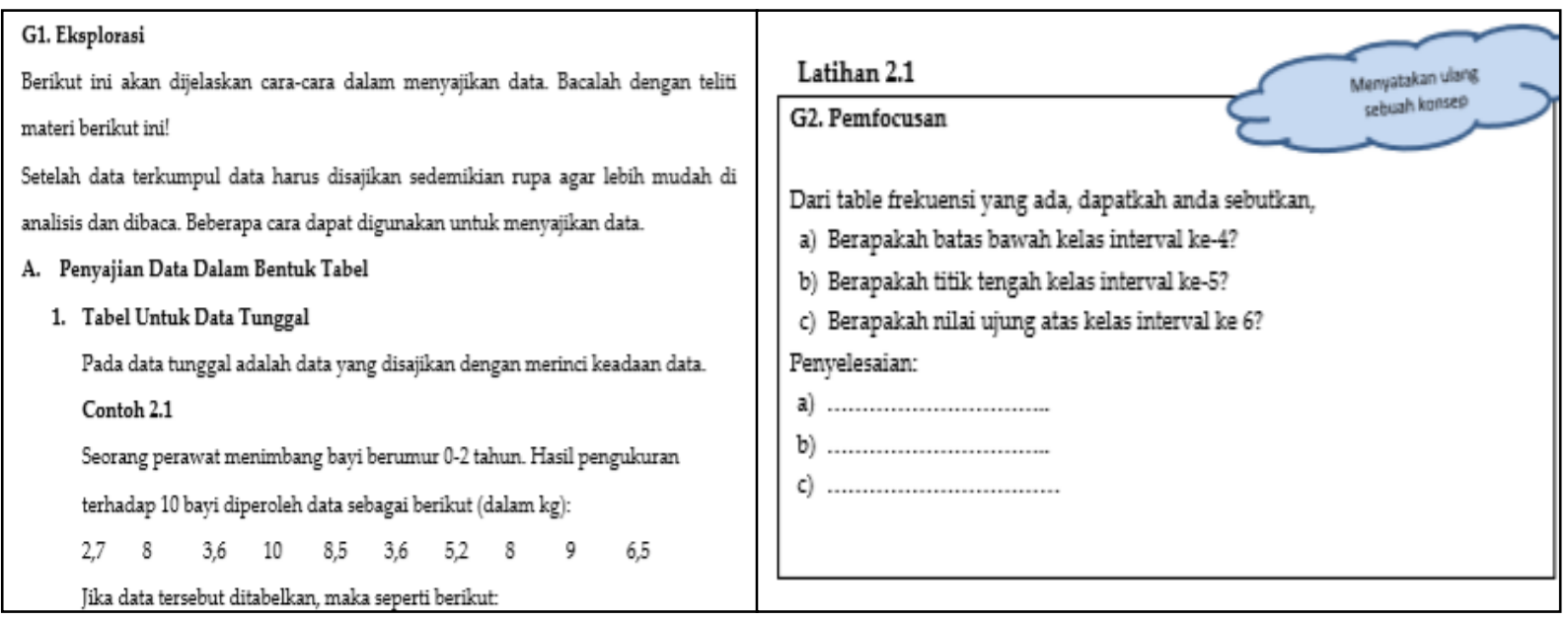

Gambar 2. Modul dilengkapi dengan Langkah

3. Tahap Pengembangan. Kegiatan yang dilakukan pada tahap ini yaitu memproduksi. Peneliti terlebih dahulu mengumpulkan semua ide dan bahan yang telah direncanakan.

a. Bahan ajar disusun dengan jenis modul berukuran 4A, yaiutu ukuran $21 \mathrm{~cm} \mathrm{x} 29,7 \mathrm{~cm}$. desain Cover dipilih dengan gambar dan symbol yang mewakili statistika. Judul modul ditulis sebaik mungkin agar lebih informatif dan dapat menggambarkan isi dari modul.

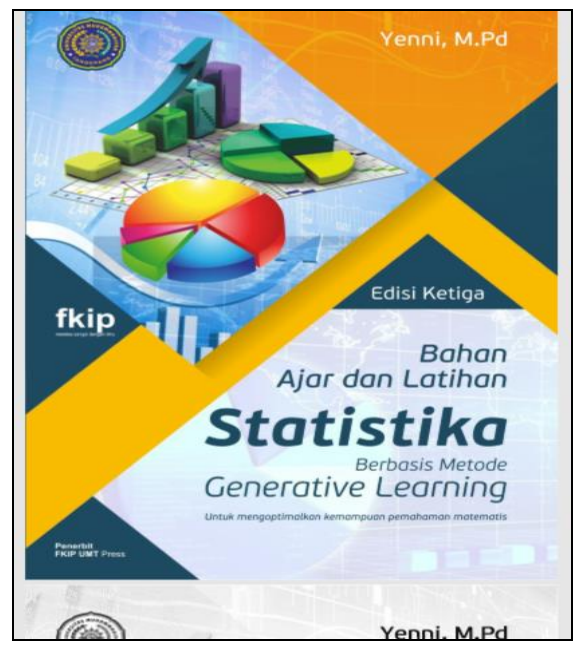

Gambar 3. Cover dan Judul Modul dicantumkan

Modul dilengkapi dengan halaman cover, kata pengantar, dan daftar isi. dan di dengan melihat: urutan materi sesuai dengan Rencana Pembelajaran semester (RPS).

b. Menyusun, mengembangkan metode dan strategi. Telah disampaikan bahwa metode yang dipilih adalah generative learning. Strategi yang digunakan agar indikator pemahaman dapat tercapai adalah dengan menerapkan langkah-langkah generative learning yang dilengkapi dengan contoh soal dan latian soal. 
c. Mengembangkan bahan ajar yang telah ada. Modul statistika ini sebelumnya adalah modul statistika yang memuat materi mata kuliah dalam satu semester. Selanjutnya, bahan ajar yang telah siap ini ditambahkan dengan kegiatan sesuai dengan langkah generative learning dan indikator kemampuan pemahaman matematis yang telah ditetapkan.

d. Mengembangkan alat evaluasi. Alat evalusi dikembangkan dengan maksud untuk menilai modul. Skor validasi menggunakan skala Likert dengan inetrpretasi $1=$ sangat kurang, $2=$ kurang, 3 = cukup, 4 = baik. Dan 5 = sangat baik. Alat evalusi tersebut adalah:

1) Instrument validasi untuk ahli pendidikan

Rata-rata hasil validasi oleh ahli pendidikan adalah 4,07 berada pada kategori baik. Terdapat tiga pernyataan dengan skor sedang, yaitu pada pernyataan aktualisasi materi, keluasan materi, dan kedalaman materi. Hal yang disaran dari ahli materi agar menambahkan materi pada ketiga hal tersebut. Selanjutnya ada lima pernyataan yang diberi nilai maksimal, yaitu tiga pernyataan pada langkah generative learning, permyataan keruntutan materi dan pernyataan soal latihan pada setiap akhir kegiatan belajar.

2) Instrument validasi untuk ahli media

Hasil validasi media memdapat skor rata-rata 3,92 termasuk kriteria baik. Beberapa indikator yang mendapat skor 3 antara lain: 1. Spasi yang terlalu rapat pada beberapa contoh soal. Menurut Ahli, sebaiknya spasi dan ukuran tulisan diperbesar agar lebih jelas membaca; 2. Kurangnya gambar ilustrasi; 3. Perlu menambahkan tempat yang lebih luas bagi mahasiswa menjawab soal.

3) Instrument validasi untuk ahli materi

Rata-rata dari hasil validasi ahli materi adalah 4,47 termasuk kriteria baik. Dari 19 pernyataan yang diberikan, 10 pernyataan mendapat skor 4 dan 9 pernyataan mendapat skor 5. Hal yang disarankan oleh ahli materi yaitu, bahwa masih ditemukan beberapa kesalahan pengetikkan.

4) Instrumen wawancara. Instrumen wawancara dipergunakan untuk memperoleh data bagaimana cara mahasiswa menjawab, serta alasan pemilihan cara menjawab soal pada tes awal. Rata-rata skor instrument wawancara oleh ahli 4,0 berada pada kategori baik.

5) Instrument Evaluasi mahasiswa. Terdapat tiga aspek utama pada angket evaluasi yang diberikan kepada mahasiswa. Pertama aspek tampilan dengan rata-rata skor 3,67 termasuk pada kategori Baik. Kedua aspek penyajian materi dengan rata-rata skor 4,54 termasuk 
pada kategori sangat baik, dan ketiga aspek manfaat dengan skor rata-rata 3,83 termasuk pada kategori baik. Secara keseluruhan, rata-rata dari angket evaluasi mahasiswa adalah 3,98, berada pada kategori baik.

6) Instrumen pemahaman matematis. Rata-rata skor instrument pemahaman matematis 4,0.

e. Memilih dan mengkombinasikan media yang terbaik untuk dapat dipergunakan dalam pembelajaran. Dalam proses belajar mengajar, selain bahan ajar sebagi alat utama, peneliti mengkombinasikan beberapa alat untuk mengefektifkan pembelajaran, diantaranya penggunaan LCD untuk menyangkan power point, kuis, dan game. Namun demikian, penambahan alau dan metode ini tidak menjadi bagian dari detail penelitian.

1) Implementasi. Pada tahap ini, peneliti menerapkan modul yang telah direvisi pada pembelajaran. Peneliti memastikan bahwa setiap mahasiswa melalui tahap-tahap generative learning sesuai rencana, serta menyelesaikan soal-soal indicator pemahaman matematis yang terdapat dalam bahan ajar. Akhir dari implementasi, peneliti memberikan tes akhir pada mahasiswa.

2) Evaluasi. Hasil tes di akhir perkuliahan menunjukkan, bahwa seluruh mahasiswa program studi pendidikan matematika kelas pagi lulus mata kuliah statistika dengan nilai baik dan sangat baik. Artinya bahan ajar yang telah di susun sangat efektif.

\section{KESIMPULAN}

Berdasarkan hasil penelitian, dapat disimpulkan bahwa penelitian pengembangan ini menghasilkan bahan ajar yang diberi judul Bahan Ajar dan Latihan Statistika Berbasis Metode Generative Learning untuk Mengoptimalkan Kemampuan Pemahaman Matematis yang valid dan efektif. Hal tersebut diperkuat dengan hasil validasi untuk ahli pendidikan 4,07, ahli media 3,92, ahli materi 4, 47. Hasil evaluasi mahasiswa 3,98 serta hasil tes akhir kemampuan mahasiswa yang menunjukkan bahan ajar sangat efektif.

\section{UCAPAN TERIMAKASIH}

Ucapan terimakasih kepada Eka Rachma Kurniasi, M. Pd, Abdul Baist, M. Si, Dian Nopitasari, M. Pd, yang telah bersedia menjadi penilai pada intrumen penelitian ini. Tidak lupa mahasiswa semester VI program studi Pendidikan Matematika tahun akademik 2018/2019 yang telah bersedia menjadi subjek uji coba kelompok kecil. 


\section{REFERENSI}

Hakim, A. R. (2014). Pengaruh Model Pembelajaran Generatif terhadap Kemampuan Pemecahan Masalah Matematika. Jurnal Ilmiah Pendidikan MIPA, 4(3), 196-207.

Hasyim, A. (2016). Metode Penelitian dan Pengembangan di Sekolah. Yogyakarta: Media Akademi

Indriani, R., dkk. (2019). Contextual Teaching and Learning Untuk Meningkatkan Kemampuan Pemahaman Konsep Pecahan. Kalamatika: Jurnal Pendidikan Matematika, 4(1), 109-116.

Karlina, E., Bektiarso, S., \& Lesmono, A. D. (2017). Penerapan Model Pembelajaran Generative Learning pada Pembelajaran Fisika Di SMA. Jurnal Pembelajaran Fisika, 6(1), 92-96.

Monalisa, L.K., Trapsilasiwi, D. (2016). Pengembangan Perangkat Pembelajaran Mata Kuliah Teori Bilangan Program Studi Pendidikan Matematika Berdasarkan Kurikulum Kulifikasi Nasional Indonesia (KKNI). Jurnal Pancaran Pendidikan, 5(4), 191-200.

Nurafni, N., Miatun, A., Khusna, H., \& Jusra, H. (2019). Pengembangan Bahan Ajar Materi Induksi Matematika dan Teori Binomial Berbasis Pembuktian. Kalamatika: Jurnal Pendidikan Matematika, 4(1), 89-108.

Ompusunggu, V. D, K. (2015). Peningkatan Kemampuan Matematik dan Sikap Positif Terhadap Matematika SMP Nasrani 2 Medan Melalui Pendekatan Problem Posing. Jurnal Saintech, 4(4), 93-15.

Pratama, D. R. Y., Kusumo, E., \& Susatyo, E. B. (2014). Keefektifan Model Pembelajaran Generatif Berfasilitas Multimedia Learning terhadap Hasil Belajar. Chemistry in Education Journal, 3(1), 12-13.

Purwosusilo. (2014). Peningkatan Kemampuan Pemahaman dan pemecahan Masalah Matematika Siswa SMK melalui Strategi Pembelajaran REACT. Jurnal Pendidikan dan Keguruan, 1(2). 
Uyun, Q., Holisin, I., \& Kristanti, F. (2017). Pengembangan Media Handout Segitiga dengan Model Problem Based Instruction. MUST: Journal of Mathematics Education, Science and Technology, 2(1), 115-128.

Rahmi Fitri (2017). Pengembangan Perangkat Pembelajaran Berbasis Pendekatan Konstruktivisme untuk Meningkatkan Kemampuan Pemahaman Konsep pada Materi Persamaan Lingkaran. Jurnal Nasional Pendidikan Matematika, 1(2), 241-157.

Sharfina, S., Halim, A., \& Safitri, R. (2017). Model Pembelajaran Generatif Terhadap Peningkatan Keterampilan Proses Sains Siswa Kelas X SMA Negeri 1 Kuala. Jurnal Pendidikan Sains Indonesia, 5(1), 102-106.

Sudyana, Kaluge, A. \& Puryanto. (2007). Efek Model Pembelajaran Generatif Terhadap Pemahaman Belajar Kimia di Kalangan Siswa SMA. Jurnal Pancaran Pendidikan, 20(67), 1079-1090.

Hamdan, S. (2013). Meningkatkan Kemampuan Berpikir Kreatif dan Disposisi Matematik Siswa Madrasah Tsanawiyah melalui Pembelajaran Generatif. Jurnal Ilmiah Program Studi Matematika STKIP Siliwangi, 2(2), 45-47.

Wisnuwijanarko. (2018). Peningkatan Keaktifan dan Hasil Belajar Melalui Model Pembelajaran Generatif Pada Materi Budidaya dan Wirausaha Tanaman Hias. Jurnal PTK dan Pendidikan, 3(2), 117-129.

Yenni, Y. (2017). Pengembangan bahan Ajar Statistika untuk mengembangkan kemampuan Pemahaman Matematis Mahasiswa Pendidikan Anak Usia Dini pada Mata Kuliah Statistika. Journal of Mathematics, Education, Science d\& Technology, 2(1), 90-102.

Yudi, M., Ariani, N.M., Ramadianti, W. (2017). Desain Bahan Ajar Mata Kuliah Aljabar Linear Untuk Mengembangkan Kemampuan Berpikir Kreatif Matematis. Kalamatika: Jurnal Pendidikan Matematika, 2(1), 1-14. 